УДК 342.9

DOI https://doi.org/10.32837/pyuv.v0i1(30).524

\author{
А. С. Лісніченко \\ orcid.org/0000-0003-0422-7467 \\ аспірант кафедри адміністративного права \\ Київького національного університету ілені Тараса Шевченка
}

\title{
АДМІНІСТРАТИВНО-ТЕРИТОРІАЛЬНІ АСПЕКТИ РЕАЛІЗАЦІЇ ТЕРИТОРІАЛЬНИМИ ГРОМАДАМИ ПРАВА НА МІСЦЕВЕ САМОВРЯДУВАННЯ
}

Постановка проблеми. Аналіз наукової літературидаєпідставистверджувати,щопитання,пов'язані з адміністративно-територіальним устроєм, здебільшого розглядаються в межах науки конституційного права. При цьому адміністративно-правова наука необгрунтовано мало уваги приділяє дослідженню таких правових категорій як «адміністративно-територіальна одиниця» $\mathrm{i}$ «територіальна громада" в їх комплексному взаємозв'язку.

Так, відсутність закону України, який визначав би засади адміністративно-територіального устрою, а також наявність інших прогалин у законодавстві України спричиняють складнощі в реалізації прав і свобод деяких категорій громадян України, зокрема тих, які проживають за межами відповідних адміністративно-територіальних одиниць, знаходяться в межах населених пунктів або їх добровільних об'єднаннях тимчасово, не мають власного представницького органу місцевого самоврядування.

Оцінка стану літератури. Питання просторових меж функціонування територіальних громад були предметом наукових досліджень таких вчених як О.І. Сушинський, О.В. Батанов, Ю.Л. Панейко та інших.

Метою статті $є$ висвітлення адміністративно-територіальних аспектів реалізації територіальними громадами права на місцеве самоврядування 3 наведенням найактуальніших положень законодавства та з урахуванням різних наукових позицій із порушеного питання.

Виклад основного матеріалу. При розкритті особливостей впливу адміністративно-територіального устрою на можливість реалізації територіальними громадами України права на місцеве самоврядування необхідно звернутися до положень Конституції України та Закону України «Про місцеве самоврядування в Україні", які, визначаючи територіальні громади як сукупність громадян України, акцентують увагу на необхідності їхнього постійного проживання в межах відповідних адміністративно-територіальних одиниць.

Як вважає професор О.І. Сушинський, ознакою територіальної громади $\epsilon$ «територіальність», тобто просторова «прив'язка» соціального утворення до певної території, яка визначає просторові межі, юрисдикцію та функціонування територіальних громад. 3 відповідних приписів Конституції Укра- їни (насамперед це ч. 1 ст. 140) вбачається, що «територіальність» громади обмежується населеними пунктами, що є самостійними адміністративно-територіальними одиницями, а також добровільними об'єднаннями жителів кількох сіл, які мають єдиний адміністративний центр [1, с. 10-11].

Територіальну основу (механізм) місцевого самоврядування в Україні, на думку професора О.В. Батанова, складають село, селище, місто, тобто право самостійно вирішувати питання місцевого значення визначається лише за територіальними колективами жителів «природних» адміністративно-територіальних одиниць (поселень). Механізм місцевого самоврядування має чітко виражений локально-територіальний характер [2, с. 67].

На думку автора, при розгляді питання про просторову організацію місцевого самоврядування необхідно враховувати, що відповідно до ч. 6 ст. 7 Виборчого кодексу України належність громадянина до відповідної територіальної громади та проживання його на відповідній території визначаються його виборчою адресою (крім випадків, передбачених законом) [3]. Частина 2 ст. 8 Закону України «Про Державний реєстр виборців» під виборчою адресою виборця розуміє адресу, за якою зареєстровано його місце проживання відповідно до Закону України «Про свободу пересування та вільний вибір місця проживання в Україні» [4].

Місцем проживання згідно зі ст. 3 Закону України «Про свободу пересування та вільний вибір місця проживання в Україні» є житло, розташоване на території адміністративно-територіальної одиниці, в якому особа проживає, а також спеціалізовані соціальні установи, заклади соціального обслуговування та соціального захисту, військові частини [5]. Закон України «Про місцеве самоврядування в Україні» (ст. 1) під адміністративно-територіальними одиницями розуміє область, район, місто, район у місті, селище, село [6]. Отже, нині нормативно закріпленою підставою віднесення громадян України до відповідної територіальної громади $є$ їх проживання в межах населених пунктів або добровільних об'єднаннях населених пунктів, що підтверджує запропоновану думку про важливість дослідження питання реалізації територіальними громадами права на місцеве самоврядування в контексті адміністративно-територіального устрою. 
Надзвичайно важливим і проблематичним із наукової та практичної точок зору є питання правового статусу громадян України, які проживають в межах військових містечок, садових чи дачних товариствах, фермах, хуторах та інших поселеннях поза адміністративно-територіальними межами населених пунктів або добровільних об'єднаннях населених пунктів. Зазначені громадяни України не можуть бути віднесені до територіальних громад, що негативно впливає на реалізацію закріплених Конституцією та законами України прав та законних інтересів, зокрема в частині цілковитого усунення їх від участі в управлінні місцевими справами.

Ускладнює проблему фрагментарність законодавчого врегулювання порушеного питання та недосконалість адміністративно-територіального устрою України, в якому дотепер залишається багато архаїзмів, отриманих у спадок від Радянського Союзу.

Одним із прикладів вирішення проблеми жителів, які проживають в межах військових містечок, є прийняття Парламентом України Постанови від 05 липня 2012 року№ 5173 -VI «Проприсвоєння найменування населеному пункту Радомишльського району Житомирської області», відповідно до якої Верховна Рада України утворила з військового містечка№6Макарів-1населенийпунктуРадомишльському районі Житомирської області шляхом присвоєння йому найменування - селище Городок [7].

В пояснювальній записці до вказаної Постанови Верховної Ради України їі авторами зазначалося, що поселення військового містечка № 6 Макарів-1 розташоване в Радомишльському районі Житомирської області на території загальною площею 1514 га. Незначна частина незаселеної його території (1/6 загальної території) розташована на території Макарівського району Київської області. На території населеного пункту проживає 2671 громадянин і знаходиться 27 багатоквартирних житлових будинків на 973 квартири, об'єкти соціально-культурної сфери, зокрема дитячий садок, загальноосвітня середня школа, музична школа, будинок офіцерів, магазин, військовий лазарет, поштове відділення, відділення банку, офіцерська та шкільна їдальні.

Проблемою жителів військового містечка є те, що цей населений пункт згідно адміністративно-територіального поділу не існує, органів місцевого самоврядування немає, жителі містечка позбавлені конституційних прав обирати та бути обраними до органів місцевого самоврядування. Внаслідок того, що військове містечко Макарів-1 відсутне в обліку населених пунктів України, кошти на розвиток його інфраструктури не виділяються [8].

Також на законодавчому рівні тимчасово було вирішено проблему жителів садових і дачних будинків шляхом прийняття Закону України від
02 вересня 2014 року № 1673-VII «Про внесення змін до деяких законодавчих актів України щодо переведення садових і дачних будинків у жилі будинки та реєстрації в них місця проживання», яким встановлено, що тимчасово (до проведення реформи адміністративно-територіального устрою) дачні поселення та садівницькі товариства у приміських зонах обліковують за тими населеними пунктами, з якими вони пов'язані адміністративно або територіально.

Тимчасово до жителів, об'єднаних постійним проживанням у межах села, селища, міста, також належать жителі, які проживають постійно за межами цих адміністративно-територіальних одиниць, але житло яких віднесено до відповідного села, селища чи міста (п. 2 р. II «Прикінцеві положення» Закону) [9].

Крім необхідності проживання громадян України в межах населених пунктів або добровільних об'єднаннях населених пунктів, варто акцентувати увагу і на необхідності постійного проживання в зазначених адміністративно-територіальних одиницях, тобто визначальною ознакою такого проживання є безстроковий характер.

Під місцем постійного проживання розуміється те місце, де громадянин розмістився в силу життєвих обставин. Тимчасовим місцем проживання $\epsilon$ місце перебування особи під час відпустки, відрядження тощо. Визначення місця проживання має суттєве юридичне значення, оскільки 3 ним пов'язуються правові наслідки здійснення багатьох правочинів [10, с. 477].

Постійність проживання громадян України в межах населених пунктів або добровільних об'єднань населених пунктів - це той фактор, який мотивує громадян до максимально швидкого та ефективного вирішення питань місцевого значення. Такі жителі більш свідомо ставляться до здійснення місцевого самоврядування, активніше вступають в адміністративні правовідносини з суб'єктами публічної адміністрації та краще обізнані з проблемними питаннями, які потребують подальшого вирішення.

Стосовно викладеного слід додати, що громадяни України реалізують право на місцеве самоврядування лише в межах адміністративно-територіальних одиниць (населені пункти або їх добровільні об'єднання) свого постійного місця проживання. В разі, якщо громадяни України перебувають на адміністративній території іншого населеного пункту або добровільного об'єднання населених пунктів, в адміністративні правовідносини з його суб'єктом публічної адміністрації вони можуть вступати лише як приватні особи.

Порядок формування складу територіальних громад, на думку автора, теж є похідним від такої правової категорії як адміністративно-територіальний устрій, оскільки межі адміністра- 
тивно-територіальних одиниць зумовлюють імперативність характеру формування складу територіальних громад.

Досліджуючи правові аспекти здійснення місцевого самоврядування український вчений-адміністративіст Ю.Л. Панейко наголошував на тому, що вступ до громади в характері їі члена, а саме можливість стати членом громади, не залежить від доброї волі цієї особи. Тут вирішальним чинником $€$ постанова закону, яка надає громаді характеру примусового об’єднання і вирішує, хто є членом громади. Зазначене можна сформулювати тільки як публічно-правовий обов'язок [11, с. 118].

Викладена наукова думка є досить обгрунтованою, оскільки належність громадян до відповідної територіальної громади визначається їх зареєстрованим місцем проживання. Так, нормативний припис закріплений у Законі України «Про свободу пересування та вільний вибір місця проживання в Україні». Він зобов'язує громадян України, а також іноземців чи осіб без громадянства, які постійно або тимчасово проживають в Україні, протягом 30 календарних днів після зняття з реєстрації місця проживання та прибуття до нового місця проживання зареєструвати своє місце проживання. Також цим Законом встановлена імперативна вимога для батьків або інших законних представників зареєструвати місце проживання новонародженої дитини протягом трьох місяців 3 дня державної реєстрації її народження [5]. Таким чином, реєстрація місця проживання автоматично включає нових жителів, які мають намір постійно проживати в населеному пункті, або добровільному об'єднанні населених пунктів до складу територіальної громади незалежно від їх волевиявлення.

Законодавство України містить низку винятків, при яких порядок формування складу територіальних громад не пов'язаний із реєстрацією місця проживання в класичному розумінні, носить добровільний характер і безпосередньо залежить від волевиявлення суб'єктів. У цьому випадку йдеться про внутрішньо переміщених осіб та жителів добровільних об'єднань населених пунктів (об’єднаних територіальних громад).

Так, в умовах анексії частини суверенної території та військової збройної агресії на Сході України, спричинених діями Російської Федерації, особливо актуальними є питання, пов'язані з інтеграцією внутрішньо переміщених осіб на новому місці проживання поза межами непідконтрольних територій. 3 цією метою Закон України «Про забезпечення прав і свобод внутрішньо переміщених осіб» передбачив можливість підтвердження факту внутрішнього переміщення довідкою про взяття на облік внутрішньо переміщеної особи, яка діє безстроково, крім випадків, передбачених цим Законом. Довідка про взяття на облік внутрішньо переміщеної особи тимчасово засвідчує місце проживання внутрішньо переміщеної особи на період збройного конфлікту або тимчасової окупації території України [12]. Особам, які були змушені покинути своє постійне місце проживання внаслідок дії надзвичайних обставин, на законодавчому рівні надано можливість за власним волевиявленням обрати нове місце проживання та добровільно увійти до складу відповідної територіальної громади.

Також Закон України «Про добровільне об’єднання територіальних громад» передбачає право жителів суміжних сіл, селищ, міст на власний розсуд вирішувати питання щодо об'єднання в одну сільську, селищну, міську об'єднану територіальну громаду з метою більш ефективного здійснення місцевого самоврядування. Положення Закону України «Про добровільне об’єднання територіальних громад» носять тимчасовий характер і насамперед спрямовані на проведення в Україні реформи адміністративно-територіального устрою в частині формування трирівневої системи (громада, округ, область).

Після об’єднання переважної більшості територіальних громад ті територіальні громади, які не виявили бажання щодо такого об'єднання, будуть примусово об’єднані в порядку, встановленому законом, на підставі перспективних планів формування територій громад Автономної Республіки Крим, областей, розроблених місцевими державними адміністраціями (Закон України від 05 грудня 2019 року № 348-XI) [13].

Одним 3 елементів територіальної організації місцевого самоврядування є необхідність існування представницьких органів місцевого самоврядування (сільських, селищних, міських рад) в межах населених пунктів або їх добровільних об'єднань, які покликані забезпечити повноцінний розвиток $\mathrm{i}$ функціонування відповідних територіальних громад. Так, представницькі органи місцевого самоврядування наділені надзвичайно широким колом повноважень, починаючи від повноважень у галузі бюджету, фінансів, цін і закінчуючи повноваженням щодо відзначення державними нагородами.

Статтею 26 Закону України «Про місцеве самоврядування в Україні» передбачено виключну компетенцію сільських, селищних, міських рад щодо прийняття рішення про проведення місцевого референдуму, затвердження статуту територіальної громади, наділення органів самоорганізації населення власними повноваженнями органів місцевого самоврядування, а також про передачу коштів, матеріально-технічних та інших ресурсів, необхідних для їх здійснення [6]. Виборні органи місцевого самоврядування - це ті суб’єкти публічної адміністрації, які зобов'язані якнайшвидше реагувати на проблеми і виклики територіальних громад, виконувати їх запити шляхом, зокрема, надання адміністративних послуг. 
Незважаючи на передбачене Конституцією України та Законом України «Про місцеве самоврядування в Україні" право територіальних громад безпосередньо здійснювати місцеве самоврядування, відсутність представницьких органів місцевого самоврядування в населених пунктах або добровільних об'єднаннях населених пунктів унеможливлює існування адміністративних правовідносин, які за своїм суб'єктним складом є як мінімум двосторонніми, що ставить під загрозу можливість забезпечення реалізації публічних інтересів жителів, які належать до територіальних громад.

Правові наслідки відсутності у територіальних громад власних представницьких органів місцевого самоврядування виявляються на прикладі населених пунктів, які знаходяться у підпорядкуванні представницького органу місцевого самоврядування іншого населеного пункту. Подібна побудова публічного адміністрування нині існує в результаті застарілого адміністративно-територіального устрою радянського зразка, який з моменту прийняття в 1996 році Конституції України не був приведений у відповідність до її положень.

Відповідно до Розділу II Положення про порядок вирішення питань адміністративно-територіального устрою Української РСР Президія Верховної Ради Української РСР і виконавчі комітети обласних, міських (міст республіканського підпорядкування) Рад народних депутатів наділялися повноваженнями 3 питань адміністративно-територіального устрою щодо зміни підпорядкування населених пунктів (Указ Президії Верховної Ради Української РСР від 12 березня 1981 року № 1654-Х) [14].

Наприклад, на підставі вказаного Положення виконавчим комітетом Львівської обласної Ради народних депутатів 29 січня 1987 року було прийнято рішення з питань адміністративно-територіального устрою відповідно до якого у Кам'янсько-Бузькому районі ліквідовано Таданівську сільську раду, а село Тадані передано у підпорядкування Кам'янсько-Бузької міської ради, в Старосамбірському районі ліквідовано Терлівську і Тисовицьку сільські ради, а села Терло і Максимівка передано в підпорядкування Старявській сільській раді, село Тисовицю - у підпорядкування Стрілківській сільській раді [15, с. 116]. Ліквідація зазначених сільських рад і передача функцій управління населеними пунктамиіншим представницьким органам місцевого самоврядування фактично позбавляє їх жителів права повноцінно брати участь у здійсненні місцевого самоврядування.

Існування такого підпорядкування суперечить правовим засадам здійснення місцевого самоврядування, закладеним в Основному Законі України та Законі України «Про місцеве самоврядування в Україні», оскільки будь-яка територіальна гро- мада має безумовне право обирати представницький орган, який буде слугувати цілям реалізації прав і свобод жителів на місцевому (самоврядному) рівні. В свою чергу можливість здійснення публічного адміністрування місцевою радою одного населеного пункту на території іншого населеного пункту законодавчо не передбачена.

Ще одним аргументом на користь вказаного вище $є$ відсутність у більшості районів у містах з районним поділом представницьких органів місцевого самоврядування. Відповідно до ч. 5 ст. 140 Конституції України питання організації управління районами в містах належить до компетенції міських рад [9], що розтлумачено Конституційним Судом України як повноваження міських рад приймати рішення щодо утворення чи не утворення в місті районних рад (п. 2 резолютивної частини Рішення Конституційного Суду України від 13 липня 2001 року № 11-рп (справа про адміністративно-територіальний устрій) [16].

За наявності в місті районного поділу та проживання в його районах громадян України міська рада з урахуванням загальноміських інтересів, колективних потреб територіальної громади міста, керуючись принципами правової, організаційної та матеріально-фінансової самостійності, на власний розсуд реалізує надане їй конституційне повноваження утворювати чи не утворювати районні в місті ради. У разі не прийняття міською радою рішення про утворення районних в місті рад говорити про існування адміністративних правовідносин на рівні району міста між його жителями та представницьким органом місцевого самоврядування цього району не можливо.

Відповідно до сучасної практики управління районами в місті міськими радами (міста Харків, Одеса, Львів, Запоріжжя) у районах міста замість районних в місті рад утворюються виконавчі органи міської ради з назвою «районні в місті адміністрації». За таких умов жителі районів міста можуть вступати в адміністративні правовідносини з міською радою або її виконавчими органами, які функціонують у районах міста, але в якості територіальної громади міста.

Окреслені проблеми потребують якнайшвидшого вирішення, зокрема шляхом прийняття Верховною Радою України Закону України «Про засади адміністративно-територіального устрою», який визначав би засади побудови адміністративно-територіального устрою, органи, до повноважень яких належить розгляд і вирішення питань адміністративно-територіального устрою, порядок утворення та ліквідації адміністративно-територіальних одиниць, встановлення і зміну їх меж, віднесення населених пунктів до категорії сіл, селищ, міст, найменування і перейменування населених пунктів, адміністративно-територіальних одиниць. 
Висновки. У статті досліджено адміністративно-територіальні аспекти реалізації територіальними громадами права на місцеве самоврядування, розглянуто важливість належного нормативно-правового регулювання адміністративно-територіального устрою для повноцінного функціонування територіальних громад і забезпечення доступу всіх громадян України до гарантованих КонституцієюізаконамиУкраїнипублічнихпослуг.

3 метою покращення спроможності територіальних громад вступати в адміністративні правовідносини з органами місцевого самоврядування, для ефективного впровадження в Україні реформи децентралізації публічної влади першим кроком має стати закріплення на законодавчому рівні трирівневої системи адміністративно-територіального устрою України (муніципалітет (добровільні об'єднання населених пунктів), округ, область). Наведений підхід забезпечить принцип повсюдності місцевого самоврядування, при якому всі без виключення громадяни України будуть проживати в межах адміністративно-територіальних одиниць, охоплених публічним адмініструванням органів місцевого самоврядування. Зазначене можна реалізувати шляхом прийняття Верховною Радою України Закону України «Про засади адміністративно-територіального устрою України».

\section{Jimepamypa}

1. Реформа місцевого самоврядування в Україні: сучасні тенденції та виклики : матеріали круглого столу, м. Львів, 18 травня 2018 р. / за наук. ред. проф. П. Гураля, проф. О. Сушинського. Львів : ЛРІДУ НАДУ, 2018. $100 \mathrm{c}$

2. Батанов О.В. Територіальна громада: основа місцевого самоврядування в Україні : монографія. Київ : Ін-т держави і права ім. В.М. Корецького НАН України, 2001. 260 с.

3. Виборчий кодекс України. URL: https://zakon.rada.gov.ua/laws/main/396-20 (дата звернення: 12.03.2020).

4.ПроДержавнийреєстрвиборців:ЗаконУкраїнивід 22.02.2007 № 698-V. URL: https://zakon.rada.gov.ua/ laws/show/698-16 (дата звернення: 12.03.2020).

5 . Про свободу пересування та вільний вибір місця проживання в Україні : Закон України від 11.12.2003 № 1382-IV.URL: https://zakon.rada.gov.ua/laws/show/ 1382-15 (дата звернення: 12.03.2020).

6. Про місцеве самоврядування в Україні : Закон України від 21.05.1997 № 280/97-BP. URL: https://zakon.rada.gov.ua/laws/show/280/97-вр (дата звернення: 12.03.2020).

7. Про присвоєння найменування населеному пункту Радомишльського району Житомирської облласті : Постанова Верховної Ради України від 05.07.2012 № 5173-VI. URL: https://zakon.rada.gov.ua/laws/ show/5173-vi (дата звернення: 12.03.2020).

8. Пояснювальна записка до проєкту Постанови України «Про присвоєння найменування населеному пункту Радомишльського району Житомирської області». URL: http://w1.c1.rada.gov.ua/pls/zweb2/ webproc4_1?pf3511=43855 (дата звернення: 12.03 .2020 ).
9. Про внесення змін до деяких законодавчих актів України щодо переведення садових і дачних будинків у жилі будинки та реєстрації в них місця проживання : Закон України від 02.09.2014 № 1673-VII. URL: https://zakon.rada.gov.ua/laws/show/1673-18 (дата звернення: 12.03.2020).

10. Великий енциклопедичний юридичний словник / за редакцією акад. НАН України Ю.С. Шемшученка. Київ : ТОВ Видавництво «Юридична думка», 2007. 992 c.

11. Юрій Панейко. Теоретичні основи місцевого самоврядування. Мюнхен : Укр. Вільна. Акад. наук у Німеччині, 1963. $193 \mathrm{c.}$

12. Про забезпечення прав і свобод внутрішньо переміщенихосіб» :ЗаконУкраїнивід20.10.2014№1706-VII. URL: https://zakon5.rada.gov.ua/laws/show/1706-18 (дата звернення: 12.03.2020).

13. Про внесення змін до Закону України «Про добровільне об'єднання територіальних громад” щодо спрощення процедури затвердження перспективних планів формування територій громад Автономної Республіки Крим, областей : Закон України від 05.12.2019 № 348-XI. URL: https://zakon.rada.gov.ua/laws/show/ 348-20\#n2 (дата звернення: 12.03.2020).

14. Положення про порядок вирішення питань адміністративно-територіального устрою Української РСР : Указ Президії Верховної Ради Української РСР від 12.03.1981 № 1654-X. URL: https://zakon.rada.gov.ua/ laws/show/1654-10?lang=en (дата звернення: 12.03.2020).

15. Відомості Верховної Ради України від 24 лютого 1987 року № 8, с. 116. URL: http://w1.c1.rada.gov.ua/ $\mathrm{pls} / \mathrm{z} 7503 / \mathrm{A} 036$ ? rdat1=09.12.2019 \&vf7551=486 (дата звернення: 12.03.2020).

16. Рішення Конституційного Суду України від 13 липня 2001 року № 11-рп (справа про адміністративно-територіальний устрій). URL: https://zakon.rada.gov.ua/laws/show/v011p710-01 (дата звернення: 12.03.2020).

\section{Анотація}

Лісніченко А. С. Адміністративно-територіальні аспекти реалізації територіальними громадами права на місцеве самоврядування. - Стаття.

Характерними для сучасної України є децентралізаційні процеси, спрямовані на посилення ролі місцевого самоврядування та надання територіальним громадам широких можливостей, що сприяє кращому вирішенню питань місцевого значення та забезпеченню балансу влади в межах суверенної території країни. Децентралізація наближає жителів, які належать до територіальних громад, до процесу здійснення публічних функцій урядування з метою задоволення їх різнобічних потреб, покладаючи при цьому на відповідних суб'єктів публічної адміністрації відповідальність за реалізацію прав таких жителів.

У сучасних дослідженнях з адміністративного права децентралізацію визначено як спосіб організації публічної влади в державі, за якого територіальній громаді надається та гарантується можливість безпосередньо або через власних суб'єктів публічної адміністрації добровільно та самостійно вирішувати питання місцевого значення, обсяг яких визначається Конституцією та законами.

Слід звернути увагу на те, що в умовах децентралізаційних процесів, які мають місце в Україні, дослідження адміністративно-територіальних аспектів організації місцевого самоврядування має надзвичайно важливе значення, оскільки визначає просторові межі діяльності всіх суб'єктів місцевого самоврядування, 
в тому числі й територіальних громад. Адміністративно-територіальна одиниця як частина адміністративно-територіального устрою України є тією просторовою площиною, яка пов'язує між собою територіальні громади і їх представницькі органи місцевого самоврядування, визначає межі виникнення адміністративних правовідносин між згаданими суб'єктами адміністративного права.

Дослідження напрацювань українських науковців та аналіз положень законодавства України засвідчив наявність низки проблем, пов'язаних із недосконалостями нормативно-правового регулювання адміністративно-територіального устрою, що створює перепони для здійснення закріпленого Конституцією України та законами України права жителів відповідних адміністративно-територіальних одиниць на місцеве самоврядування. За цієї умови певні категорії жителів не мають змоги вступати в адміністративні правовідносини з органами місцевого самоврядування з метою забезпечення реалізації своїх публічних інтересів. Загалом статтю присвячено висвітленню адміністративно-територіальних аспектів, які впливають на реалізацію територіальними громадами України права на місцеве самоврядування.

Ключові слова: територіальні громади, органи місцевого самоврядування, суб'єкти публічної адміністрації, адміністративно-територіальний устрій, адміністративні правовідносини.

\section{Summary}

Lisnichenko A. S. Administrative-territorial aspects of realization of local self-government by local communities. - Article.

Decentralization processes that are currently taking place in Ukraine, aimed at enhancing the role of local self-government and giving local communities ample opportunities, which certainly contributes to a better resolution of issues of local importance and maintain balance of power within the sovereign territory of Ukraine.
Decentralization brings residents closer to the process of public governance to meet their diverse needs, while placing responsibility for rights realization of such residents on the respective subjects of public administration.

In modern administrative law studies, decentralization is defined as a way of organizing public authority in a state in which the local community is given and guaranteed the opportunity, either directly or through its own subjects of public administration to voluntarily and independently resolve issues of local importance, within the limits of the Constitution and laws. It should be noted that in the context of the decentralization processes taking place in Ukraine, research of the administrative-territorial aspects of local self-government is extremely important as it defines the territorial boundaries of the activities of all subjects of local self-government, including local communities.

The administrative-territorial unit as part of the administrative-territorial structure of Ukraine is the limited area that connects local communities and their representative bodies of local self-government, defines the limits of the arising of administrative legal relations between the mentioned subjects of administrative law. Research of Ukrainian scientists and analysis of the provisions of the Ukrainian legislation revealed a number of problems related to the imperfections of regulatory of administrative-territorial structure, which, in turn, creates obstacles to local self-government rights realization of respective administrative-territorial units residents.

Under this condition, certain categories of residents are unable to enter into administrative legal relations with local governments in order to ensure the realization of their public interests. Given the urgency of the problem, the article is devoted to the coverage of administrative-territorial aspects of local self-government right realization by local communities in Ukraine.

Key words: local communities, bodies of local self-government, subjects of public administration, administrative-territorial structure, administrative legal relations. 